\title{
PEMAKNAAN ORANG TUA YANG KEHILANGAN ANAK DALAM PERISTIWA KEKERASAN POLITIK: STUDI FENOMENOLOGI
}

\author{
Stefany Valentia ${ }^{1}$ \& Winarini Wilman D. Mansoer ${ }^{2}$ \\ Fakultas Psikologi Universitas Indonesia, Jl. Margonda Raya, Pondok Cina, Beji, Depok 16424, Indonesia
}

Korespondensi:

'e-mail: stefany.valentia@ui.ac.id

\begin{abstract}
This study aims to discover the experience of parents who lost their child as a result from political violence in 1998 and to outline their meaningmaking process after the loss of their child. The study was conducted using qualitative method with phenomenological approach. Participants were parents of an undergraduate student who became the victim of the incident (some refer them as 'Reformation Heroes'), approached through convenience sampling. Data were collected by using in-depth interviews. Several themes elicited from the interview results in both parents: sorrow and resentment; refusal of loss; loss of happiness, warmth, enthusiasm, and hope; detachment from social life; social support; justice effort; and faith. Analytical findings showed that eventhough the incident has occured more than 20 years ago, participants were still going through complicated grief. Parents construe their child's death as an ongoing sacrifice effort for justice, hence they are commited to end it by demanding legal justice.
\end{abstract}

Article history:

Received 23 February 2019

Received in revised form 24 March 2019

Accepted 28 April 2019

Available online 7 June 2019

Keywords:

child loss;

parents meaning-making;

political violence;

Semanggi I tragedy

\begin{abstract}
Abstrak - Penelitian ini bertujuan untuk memahami pengalaman dan pemaknaan orang tua yang anaknya meninggal dalam peristiwa kekerasan politik pada tahun 1998. Penelitian dilakukan dengan metode kualitatif dan pendekatan fenomenologi. Partisipan merupakan orang tua dari mahasiswa yang menjadi korban pada peristiwa tersebut (sering disebut sebagai Pahlawan Reformasi) dan partisipan dipilih berdasarkan ketersediaan sumber daya peneliti. Pengambilan data dilakukan melalui proses wawancara mendalam. Dari hasil wawancara dengan partisipan, ditemukan beberapa tema dalam pengalaman dan pemaknaan ayah maupun ibu, yaitu kesedihan mendalam; kemarahan yang besar; tidak menerima kematian anak; kehilangan kebahagiaan, kehangatan, semangat, dan harapan; menarik diri dari kehidupan sosial; bangkit karena dukungan sosial; memperjuangkan keadilan hukum; serta keimanan. Hasil analisa menunjukkan bahwa meskipun sudah 20 tahun lebih berlalu sejak peristiwa kematian anak, partisipan masih terus mengalami perasaan berduka yang kompleks. Kedua orang tua memaknai kematian anak mereka sebagai pengorbanan dan perjuangan yang belum selesai. Oleh karena itu, mereka berkomitmen untuk menyelesaikan perjuangan tersebut dengan menuntut keadilan hukum.
\end{abstract}

Kata Kunci: kematian anak; pemaknaan orang tua; kekerasan politik; tragedi Semanggi I

Handling Editor: Karel Karsten Himawan, Faculty of Psychology, Universitas Pelita Harapan, Indonesia

(c) (7) This open access article is licensed under Creative Commons Attribution License, which permits unrestricted use, distribution, and reproduction, provided the original work is properly cited. 


\section{PENDAHULUAN}

Pada bulan November 1998, terjadi pergolakan besar dalam masa pemerintahan transisi di Indonesia karena ketidakpercayaan publik terhadap pemerintah. Para mahasiswa mengadakan demonstrasi besar di jalan-jalan raya di Jakarta, menuntut pembersihan pemerintah dari rezim Orde Baru. Ratusan mahasiswa melakukan pawai ke gedung DPR / MPR untuk melakukan demonstrasi, tetapi pihak berwenang mulai menembaki mereka di jalan. Ratusan orang terluka dan total 17 orang meninggal akibat penembakan, termasuk mahasiswa dari berbagai universitas, pasukan keamanan, dan warga sipil (Lestari, 2018).

Walaupun kematian merupakan sesuatu yang tak terelakkan dalam hidup, tetapi kematian seorang anak sulit diterima oleh orang tua (Arnold \& Gemma, 2008; Lichtenthal, Neimeyer, Currier, Roberts, \& Jordan, 2013) karena sewajarnya, orang tua diperkirakan akan meninggal terlebih dahulu dibandingkan dengan anak mereka. Bagi sebagian orang tua, reaksi duka yang intens akan berkurang seiring berjalannya waktu dengan peningkatan keberfungsian hidup 1.5 tahun setelah kematian anak (Murphy, Johnson, Chung, \& Beaton, 2003), namun proses duka dapat berbeda-beda pada setiap individu. Kematian anak dapat membuat identitas dan peran individu sebagai orang tua terganggu, serta membuat orang tua kehilangan tujuan hidup (Matthew \& Marwit, 2004).

Penyebab kematian anak menjadi prediktor terhadap penyesuaian diri orang tua. Hal ini ditemukan dalam studi oleh Wijngaards-de Meij et al. (2005), di mana kematian anak yang tidak terduga berasosiasi dengan reaksi dan gejala-gejala duka yang lebih intens dan traumatis. Kematian anak yang tidak terduga dapat mengakibatkan dampak yang buruk bagi orang tua (Kristensen, Weisæth, \& Heir, 2012). Terlebih lagi, kematian anak yang diakibatkan peristiwa kekerasan membuat orang tua memiliki risiko lebih tinggi untuk mengalami reaksi berduka yang kompleks dibandingkan dengan orang tua yang anaknya meninggal karena sakit (Kristensen, Weisæth, \& Heir, 2012).

Beberapa studi berupaya membandingkan strategi adaptasi antara orang tua yang kehilangan anak karena penyebab natural dan orang tua yang kehilangan anak karena peristiwa kekerasan (Lichtental, Neimeyer, Currier, Roberts, \& Jordan, 2013; Wijngaards-de Meij et al., 2008). Ratarata studi menemukan tingkat adaptasi dan perkembangan diri yang lebih baik pada orang tua yang anaknya meninggal karena penyebab kematian yang natural. Pada kematian natural, misalnya karena penyakit, orang tua memiliki kepercayaan bahwa anak tidak lagi menderita. Kepercayaan 
tersebut dapat menjadi dasar bagi orang tua untuk kemudian memaknai peristiwa kehilangan anak (Lichtental, Neimeyer, Currier, Roberts, \& Jordan, 2013).

Studi lain oleh Song, Floyd, Seltzer, Greenberg, dan Hong (2010) menemukan bahwa orang tua yang kehilangan anak mereka dalam peristiwa-peristiwa seperti kecelakaan, pembunuhan, dan bunuh diri memiliki kualitas hidup yang lebih buruk dibandingkan dengan orang tua yang kehilangan anaknya karena penyakit kronis. Hasil ini diperkuat juga dalam studi yang dilakukan oleh Lichtenthal, Neimeyer, Currier, Roberts, dan Jordan (2013). Dalam penelitian mereka, ditemukan bahwa lebih dari 50 persen orang tua yang menjadi partisipan penelitian mengatakan bahwa mereka tidak dapat memaknai kematian anaknya yang disebabkan oleh peristiwa kekerasan.

Bahkan, ketika dibandingkan antara kematian anak karena bunuh diri dengan kematian karena kekerasan, tingkat distres yang lebih tinggi ditemukan pada orang tua yang anaknya meninggal karena peristiwa kekerasan (Murphy, Johnson, Wu, Fan, \& Lohan, 2003). Penelitian tersebut menjelaskan bahwa kemungkinan pada kasus anak yang bunuh diri, orang tua sudah dapat mengantisipasi secara tidak langsung kematian anak melalui peristiwa-peristiwa atau kekacauan yang menjadi pemicu kejadian bunuh diri tersebut.

Kurang lebih 20 tahun telah berlalu sejak peristiwa kekerasan politik besar-besaran terjadi di Indonesia pada tahun 1998, namun tidak banyak yang diketahui mengenai pengalaman orang tua setelah kehilangan anaknya dalam peristiwa kekerasan politik. Kematian karena kekerasan politik adalah kasus yang unik dan berbeda, di mana kekerasan tersebut melibatkan kepentingan negara sehingga terdapat ketidakseimbangan kekuatan antara negara dan masyarakat sipil. Maka, penting untuk meneliti pengalaman dan pemaknaan orang tua terhadap peristiwa kematian anaknya dalam kekerasan politik guna memperoleh pemahaman yang lebih mendalam mengenai pengalaman tersebut.

Hingga saat ini, hanya sedikit penelitian yang menjelaskan mengenai pemaknaan orang tua yang kehilangan anak mereka dalam peristiwa kekerasan politik di Indonesia, terutama dalam perjalanan 20 tahun sejak peristiwa tersebut terjadi. Oleh karena itu, penelitian ini hendak memberikan sumbangsih literatur terkait fenomena tersebut. Diharapkan penelitian ini dapat bermanfaat bagi partisipan sebagai sarana untuk mengekspresikan hal-hal yang belum dapat diungkapkan serta sebagai sarana untuk merefleksikan diri. Bagi praktisi klinis, penelitian ini bermanfaat untuk merencanakan dan membentuk intervensi klinis yang sesuai dalam konteks orang tua yang kehilangan anaknya dalam kekerasan politik. Bagi masyarakat dan lingkungan publik, penelitian ini dapat memberikan pemahaman mendalam mengenai pemaknaan orang tua yang 
kehilangan anaknya dalam kekerasan politik, serta menjadi acuan dalam pengembangan kebijakankebijakan sosial.

\section{Griefing dan Bereavement}

Peneliti dan praktisi klinis menggunakan berbagai istilah berbeda untuk menggambarkan bagaimana pengalaman manusia dalam menghadapi kematian seseorang yang dekat dengan dirinya. Grief dapat diartikan sebagai respons terhadap kehilangan, terutama kehilangan orang yang dicintai; sedangkan bereavement (kedukaan) dapat didefinisikan sebagai kondisi kehilangan itu sendiri. Seseorang yang mengalami kehilangan disebut sebagai orang yang berduka (Worden, 2008). Terdapat beberapa ahli yang mencoba untuk menjelaskan mengenai grief, bereavement, dan prosesnya. Model griefing yang paling terkenal berasal dari Kübler-Ross (1970). Kübler-Ross berpendapat bahwa ada lima tahap grief yang disebut denial, anger, bargaining, depression, dan acceptance. Dalam model ini, individu yang berduka mengalami keadaan emosional dan kognitif yang khas di masing-masing tahapan. Denial ditandai dengan perasaan terkejut dan tidak percaya; anger ditandai dengan perasaan marah yang kuat; bargaining adalah suatu bentuk mekanisme pertahanan rasionalisasi; depression ditandai dengan perasaan hampa; dan terakhir acceptance adalah tahap di mana kematian dapat diterima.

Model duka ini dapat muncul secara bersamaan dan tidak berurutan. Individu yang berduka dapat kembali ke tahapan sebelumnya di kemudian hari. Stroebe, Schut, dan Finkenauer (2013) menemukan bahwa tidak ada cara spesifik dalam berduka, namun setiap individu memiliki cara berduka masing-masing. Proses duka orang tua adalah perjalanan seumur hidup, di mana orang tua mengalami transformasi sambil tetap berpegang pada ingatan akan anak yang telah meninggal. Duka orang tua tersebut membantu mereka untuk mempertahankan perasaan terkoneksi dengan anak yang telah meninggal. Proses berduka dapat digambarkan sebagai cara untuk menerima dan mengintegrasikan kehilangan tersebut ke dalam kehidupan saat ini. Orang tua akan mengalami perubahan seumur hidup yang mengubah identitas dan perspektif mereka akan hidup (Arnold \& Gemma, 2008).

\section{Kematian karena Kekerasan}

Ditemukan bahwa individu yang berduka karena kematian mendadak akibat peristiwa kekerasan memiliki risiko yang lebih tinggi untuk mengalami reaksi duka yang rumit dibandingkan dengan mereka yang berduka karena penyebab kematian yang wajar (Kristensen, Weisæth, \& Heir, 
2012). Song, Floyd, Seltzer, Greenberg, dan Hong (2010) menemukan bahwa orang tua yang kehilangan anak mereka karena peristiwa kekerasan, seperti kecelakaan, pembunuhan, dan bunuh diri, berdampak pada proses berduka yang lebih buruk dibandingkan dengan orang tua yang kehilangan anak karena penyakit kronis. Dalam analisis yang dilakukan oleh Bauwens (2017) terhadap grey literature (penelitian, tesis, disertasi yang tidak dipublikasi), salah satu tema yang muncul dalam semua studi yang dievaluasi adalah penjelasan partisipan mengenai perasaan duka yang berkelanjutan terkait kematian orang yang dikasihi dalam peristiwa teror. Partisipan mendeskripsikan duka mereka sebagai perasaan mati rasa yang berkelanjutan, perasaan jauh, dan kerinduan akan anggota keluarga mereka yang meninggal.

Penelitian lain menemukan bahwa orang tua yang kehilangan anaknya dalam peristiwa kekerasan mendeskripsikan dunia sebagai tempat yang penuh ketidaksempurnaan dan hidup adalah perjalanan yang singkat, sedangkan orang tua yang kehilangan anaknya karena penyebab yang wajar (misalnya: sakit), memiliki kecenderungan untuk mengalami pertumbuhan pribadi (Lichtenthal dkk., 2013). Secara umum, pencarian makna akan menjadi lebih sulit pada orang tua yang kehilangan anaknya karena peristiwa kekerasan dibandingkan karena masalah kehamilan, kelahiran, penyakit, atau penyebab natural lainnya. Penjelasan mengenai hasil penelitian ini adalah pada peristiwa kekerasan, kematian anak adalah sesuatu yang mendadak dan tidak diduga, sehingga orang tua tidak memiliki waktu untuk memproses kematian anak dan mengalami kesulitan untuk memaknai kematian anak tersebut. Namun, pada kasus kematian yang natural, orang tua sudah lebih mengantisipasi sehingga lebih mudah untuk memaknai peristiwa kematian anak (Lichtenthal dkk., 2013).

\section{METODE}

\section{Partisipan}

Partisipan dalam penelitian ini adalah sepasang orang tua yang kehilangan seorang anak lakilaki dalam peristiwa kekerasan politik di Jakarta, Indonesia pada tahun 1998. Ayah dari korban berusia 69 tahun, sedangkan ibu korban berusia 67 tahun. Keduanya beragama Katolik. Ayah bekerja sebagai karyawan di perusahaan swasta yang melakukan penelitian kebijakan dan analisa strategis dalam hal politik dan ekonomi, sedangkan ibu sudah pensiun sejak tahun 2006 awal. Sebelumnya, ibu bekerja sebagai anggota DPR di salah satu fraksi. Saat ini, keduanya tinggal di Jakarta bersama dengan adik perempuan dari korban. Partisipan direkrut dengan metode 
convenience sampling karena asas ketersediaan sumber daya yang dimiliki peneliti (Kumar, 2011). Pada saat peristiwa tersebut terjadi, anak partisipan merupakan seorang mahasiswa yang tergabung dalam Tim Relawan Kemanusiaan (TRK) yang setelah peristiwa penembakan itu sering disebut sebagai Pahlawan Reformasi oleh beberapa kalangan.

\section{Desain}

Penelitian ini menggunakan pendekatan kualitatif dengan metode fenomenologi untuk menggali pengalaman dan pemaknaan orang tua yang kehilangan anak dalam peristiwa kekerasan politik. Studi fenomenologi adalah bagian dari pendekatan kualitatif yang berfokus pada pemaknaan individu akan suatu pengalaman (Creswell, 2007). Fenomena dalam penelitian ini adalah pengalaman orang tua yang kehilangan anaknya dalam peristiwa kekerasan politik 1998.

\section{Prosedur}

Pengumpulan data dalam penelitian ini dilakukan melalui wawancara dengan pertanyaan terbuka. Partisipan mengikuti tiga sesi wawancara dengan waktu sekitar 2-3 jam untuk setiap sesinya sesuai dengan kondisi partisipan. Wawancara dilaksanakan di rumah partisipan pada waktu yang sesuai dengan kesepakatan dan kesediaan waktu partisipan. Seluruh sesi wawancara direkam dengan perekam suara untuk ditranskrip verbatim dan dianalisis. Untuk memastikan keakuratan data, partisipan diberikan salinan transkrip wawancara dan diminta untuk memverifikasi ketepatan data atau mengklarifikasi data yang kurang tepat.

\section{Teknik Analisis}

Jenis teknik analisis yang digunakan adalah analisis tematik yang dilakukan melalui tiga langkah. Pertama, data hasil wawancara yang terkumpul ditranskrip atau dipaparkan secara apa adanya. Dengan metode epoche, pengalaman partisipan dideskripsikan untuk menemukan inti dari fenomena yang dialami. Kedua, coding data, yaitu mencari pernyataan-pernyataan yang relevan dengan fokus penelitian. Dalam mengklasifikasi tema yang muncul, beberapa pernyataan serupa akan dikelompokkan dan kemudian dianalisis dengan literatur yang sesuai. Ketiga, analisis dan penarikan kesimpulan. Untuk menginterpretasi data, dilakukan deskripsi tekstural mengenai apa yang terjadi dan bagaimana fenomena tersebut dialami (Creswell, 2007). 


\section{ANALISIS DAN HASIL}

Terdapat beberapa tema yang muncul dari hasil wawancara dengan kedua orang tua. Masing-masing memiliki perbedaan dalam melihat pengalaman kehilangan anak, namun terdapat pula beberapa tema yang sama antara kedua orang tua. Berikut adalah beberapa tema yang muncul pada ibu.

\section{Tema pada Ibu 1: Mati Rasa}

Ibu menyampaikan bahwa pada saat pertama kali mengetahui berita kematian anaknya, ia tidak dapat merasakan apa-apa. Perasaan 'mati rasa' ini cukup sering diulang oleh ibu untuk menegaskan bahwa ia tidak dapat merasakan apapun terkait kematian sang anak. Perasaan mati rasa tersebut bertahan sampai saat ini, di mana ibu merasa terbiasa karena sering menceritakan pengalaman terkait kematian anak terhadap banyak orang.

"Kalau perasaan sih.. saya bilang.. saya mati rasa.. gak bisa ngerasain apa-apa. Gak bisa. Sedih, nangis tapi gak merasakan sedih gitu, nggak. Marah juga nggak."

\section{Tema pada Ibu 2: Kehilangan Kebahagiaan dan Kehangatan}

Kematian anak dirasakan membawa perubahan dalam diri ibu. Hal ini dapat dilihat dari pernyataan ibu dalam menggambarkan kehidupan pernikahan dan kehidupan keluarga mereka. Ia merasa bahwa sebelumnya kehidupannya bahagia dan memuaskan, namun kebahagiaan tersebut seperti terputus setelah kejadian penembakan anaknya dalam peristiwa kekerasan politik. Ibu menggambarkan bahwa seperti ada garis pembatas antara kehidupan bersama anak pertamanya dan kehidupan tanpa kehadiran anak pertamanya.

\footnotetext{
"Saya merasakan sebagai orang tua, saya sudah... bisa mengantarkan anak-anak saya sampai menjadi mahasiswa. Anak saya tidak terlibat tawuran, tidak terlibat obat-obatan terlarang. Bagi saya itu kebahagiaan yang luar biasa, bagi saya. Eh, tiba-tiba anak saya ditembak. Nah yang waktu saya gambar yang di cerita itu ya ... gambarnya cuma garis aja. Dari landai, naik, langsung di puncak itu langsung jleg (jatuh ke bawah) ... menggambarkan perjalanan kehidupan saya."
}

Proses duka tidak hanya dihadapi oleh individu saja. Kematian anak juga berdampak terhadap perubahan relasi dan komunikasi dalam keluarga. Ibu juga sempat beberapa waktu mengabaikan tanggung jawabnya sebagai ibu rumah tangga, seperti tugas memasak dan membersihkan rumah. 
"Tapi kelihatan masing-masing, artinya.. ketika saya ... apa namanya ... hanya membaca kitab suci, nangis, berdoa, gitu ya, bapak ketika hobinya baca nulis, ya dia di meja makan baca nulis gitu. Diem. Jadi sunyi. Anak saya yang satu lagi kalau sudah selesai kuliah gitu belajar, ya nonton TV, itu sendiri. Situasi di rumah seperti itu kalau menurut saya. Sampai bertahun-tahun. “

Ibu menggambarkan situasi di rumah dan relasi mereka dalam keluarga sebagai sesuatu yang datar dan tidak ada semangat. Ibu bahkan tidak terlalu memperhatikan anaknya yang satu lagi karena terlalu fokus pada dirinya sendiri. Situasi seperti itu dirasakannya di dalam keluarga sampai sekitar 12 tahun setelah kematian anaknya.

\section{Tema pada Ibu 3: Kesedihan yang Mendalam}

Meskipun ibu mengatakan bahwa ia tidak dapat merasakan apa-apa, namun ia menunjukkan reaksi fisiologis berupa menangis hampir sepanjang waktu di masa-masa awal kematian anaknya. Ia menceritakan bahwa dirinya menangis setiap hari untuk waktu yang lama, juga ketika pergi ke gereja atau ketika bercerita pada orang lain.

"Setiap hari itu kerjaannya mojok di situ itu (menunjuk dekat pintu rumah), nungguin koran Kompas. Terus.. berdoa, nangis, baca kitab suci, dari hari ke hari."

Bahkan ibu sempat mempertanyakan mengapa dirinya sangat mudah menangis, tetapi di dalam tangisan tersebut ia tidak dapat merasakan sedih. Ibu juga enggan mendatangi undangan resepsi pernikahan dari orang-orang di sekitar ataupun kegiatan-kegiatan lain yang bersifat penuh kegembiraan hingga saat ini. Ibu merasa bahwa seiring berjalan waktu, akhir-akhir ini ia memiliki niat untuk ikut bergabung dalam kegiatan di lingkungannya, namun dirinya merasa belum siap secara mental.

\section{Tema pada Ibu 4: Menarik Diri}

Dalam melewati hari-hari awal menghadapi kematian sang anak, ibu cenderung enggan untuk bersosialisasi dengan orang lain, bahkan ia sempat ingin berhenti dari pekerjaannya.

"Tetapi rasa untuk bergaul dengan orang saya gak sanggup... Saya bilang 'Aku mau keluar kerja. Aku gak sanggup ketemu sama teman-teman."

Ibu memutuskan untuk menarik diri karena melihat korban lain yang diperlakukan kurang menyenangkan oleh orang-orang sekitar. Menurutnya, beberapa korban yang mengalami kasus 
serupa justru mendapatkan cemoohan dari tetangga-tetangganya, bahkan mereka sering disindir terkait dengan uang kompensasi yang didapat dari pemerintah. Ibu mengaku menolak dana kompensasi sebesar Rp 5.000.000,00 yang diberikan oleh pemerintah melalui PMI DKI dalam bentuk cek, dan mengembalikannya untuk disumbangkan kepada aparat yang bertugas pada hari penembakan anaknya.

\section{Tema pada Ibu 5: Marah pada Pemerintah}

Ibu juga merasakan perasaan marah terkait dengan kejadian penembakan anaknya. Kemarahan ibu dapat dilihat dalam perilaku dan perkataan kepada orang lain, terutama kepada orang-orang yang dianggapnya berada di pihak pemerintah. Perasaan marah muncul kepada pemerintah karena ia merasa pemerintahlah yang menyebabkan kematian anaknya. Kata marah berulang kali diucapkan ibu dalam proses wawancara.

"Waktu hari Sabtu itu kan datang orang-orang berseragam ya, ada pak camat, rupanya pak walikota juga datang. 'Pergi dari rumah saya! Jangan injak rumah saya. Teman-teman kamu yang membunuh anak saya!' saya marah-marahin gitu."

Namun perasaan marah tersebut rumit untuk dijelaskan, karena sebenarnya ia tidak mengetahui kepada siapa rasa marah tersebut harus ditujukan. Ketika ibu hanya seorang sendiri di rumah, atau saat ia berdoa, ia mengatakan bahwa ia tidak bisa merasakan kemarahan tersebut. Menurutnya, marah pun tidak akan mengubah apa-apa, karena anaknya sudah meninggal dan kematian anaknya tersebut tidak dapat diubah.

\section{Tema pada Ibu 6: "Saya Korban"}

Ibu memandang dirinya sebagai korban politik. Hal ini dapat dilihat dari beberapa kali pengulangan pernyataan bahwa dirinya adalah korban. Dalam menceritakan beberapa rangkaian kejadian pun, ibu mengacu dirinya dengan kata ganti orang ketiga, yaitu korban.

"Jadi saya itu kerja di lembaga politik, suami saya kerja di lembaga politik, menjadi korban politik hahaha ... Di universitas X itu ada, saya pernah dijadikan dosen tamu. Saya gak mau, saya gak mau disebut dosen tamu. Saya korban, ya korban."

\section{Tema pada Ibu 7: Bangkit karena Dukungan Sosial}

Dalam melewati masa-masa sulit terkait kehilangan anaknya, dukungan dari orang-orang sekitar dirasakan sangat membantu. Dukungan yang diterima menjadi salah satu kekuatan yang 
mendorong ibu untuk bangkit kembali, terutama karena ibu sempat menarik diri dari lingkungan sekitarnya, namun orang-orang di sekitarnya justru memberikan perhatian dan semangat.

"Tapi orang itu giliran sampe.. dari hampir sampe pagi itu sampai bertahunan ya, itu selalu banyak yang dateng ke rumah. Ya kemudian terus rasa.. terima kasih saya dalam bentuk apa, ya saya harus bisa hidup seperti biasa."

Ibu merasa bahwa keputusannya untuk menarik diri adalah hal yang tepat karena dari situ ia justru mengetahui bahwa banyak orang yang dengan tulus mendukung dirinya.

\section{Tema pada Ibu 8: Memperjuangkan Keadilan Hukum}

Ibu menyampaikan bahwa cinta kepada sang anak membuat dirinya mampu bertahan dalam melewati masa duka. Cinta ibu kepada anaknya diwujudkan dalam tindakan-tindakan untuk menegakkan keadilan dan memperjuangkan kebenaran hukum. Ibu juga terlibat dalam berbagai aktivitas yang bertujuan untuk mencari kebenaran dan memperjuangkan keadilan terkait dengan kasus penembakan sang anak. Aktivitas-aktivitas tersebut pada akhirnya menjadi cara untuk bertahan dan bangkit kembali dalam menghadapi peristiwa kehilangan. Melanjutkan perjuangan anak juga menjadi salah satu cara untuk memaknai peristiwa kematian sang anak. Tindakantindakan nyata dilakukan atas dasar keinginan untuk meningkatkan kesadaran masyarakat dan anak muda akan kasus pelanggaran HAM. Ibu mengatakan bahwa ia senang ketika banyak orang, terutama anak muda, memerhatikan dan merasa terinspirasi dari aksi yang ia lakukan.

\footnotetext{
"Itu yang kemudian, yang akhirnya menyemangati saya ingin melanjutkan perjuangan anak saya yang belum selesai yang menjadi apa ya, yang menjadi keinginan saya untuk memaknai.. pengorbanan dan perjuangan anak saya itu, saya ingin mewujudkan tegaknya supremasi hukum."
}

\section{Tema pada Ibu 9: Membantu Orang Lain yang Senasib}

Perubahan merupakan suatu hal yang tidak dapat dipungkiri, terutama akibat kematian orang yang disayang. Tetapi perubahan tersebut ternyata juga dapat menuju ke arah perkembangan diri yang positif, di mana ibu yang tadinya tidak suka membaca, sekarang menjadi sering menulis artikel dan berbicara di forum-forum, atau diundang sebagai pembicara di universitas. Pada mulanya, ibu hanya memperjuangkan kasusnya sendiri, namun kemudian ia menyadari bahwa banyak korban politik yang sebenarnya tidak memiliki pengetahuan yang cukup akan masalah politik. Oleh karena itu, saat ini ia banyak mewakili korban dari berbagai kasus untuk menyuarakan 
hak mereka. Ibu juga mulai terlibat dalam membantu menyemangati para orang tua lain yang mengalami kasus serupa, memperjuangkan hak asasi mereka, serta membentuk paguyuban yang menyediakan dukungan secara emosional bagi para orang tua yang menjadi korban peristiwa kekerasan politik. Bahkan ia sempat menggambarkan dirinya sendiri seperti 'pasien yang menjadi dokter'. Ibu menerima banyak komentar dari orang di sekitarnya bahwa ia dimanfaatkan oleh Lembaga Swadaya Masyarakat (LSM), namun ia merasa hal tersebut bukanlah suatu masalah. Ia merasa dengan demikian justru ia dapat menjadi berkat bagi orang lain. Menurutnya, manusia tidak dapat hidup sendiri-sendiri dan saling membutuhkan bantuan orang lain.

"Saya merasakan itu. jadi kalau korban-korban suka pada komentar, kita itu dimanfaatkan LSM gitu. ya gak apa-apa. Kalau kita bisa memberikan berkat, kalau kita bisa membantu kenapa tidak? Saya bilang gitu. Kan kita kan saling memerlukan."

Di samping itu, ibu juga tidak menolak ketika ada orang-orang yang ingin bertemu dan mengetahui kisah hidupnya, seperti misalnya wartawan ataupun mahasiswa yang melakukan penelitian. Menurutnya, hal itu juga membantu dirinya sekaligus membantu orang lain. Ia berharap bahwa apa yang ia lakukan saat ini dapat bermanfaat, meskipun hanya untuk segelintir orang. Dengan demikian, ia merasa bahwa orang lain juga dapat merasakan buah dari hasil ziarah hidup anaknya.

\section{Tema pada Ibu 10: Iman sebagai Sumber Kekuatan}

Iman menjadi sumber kekuatan yang membantu ibu untuk menerima dan memaknai peristiwa kematian anaknya. Dalam memperjuangkan keadilan, ibu mendasarkannya pada iman dan ajaran gereja. Ibu mengetahui bahwa kematian merupakan sesuatu yang tidak terelakkan, sehingga yang menjadi penting adalah kontribusi dan manfaat yang diberikan seseorang kepada lingkungannya selama ia hidup. Ia mengatakan bahwa kalau memang kematian anaknya adalah kehendak Tuhan, maka ia tidak bisa menolak.

\footnotetext{
"Dan memang saya lebih dikuatkan dengan iman ... Bagi saya kembali ke iman, masalah iman ya... Anak saya itu yang dipilih ya, dipilih Tuhan untuk menjadi alat, alat... di dalam mengkritisi situasi politik pada tahun 1998. Kalau dipikir-pikir, masa sih anak saya bisa memberikan seminar di fakultas lain."
}

Ibu juga menyampaikan bahwa ia mensyukuri berkat Tuhan lewat orang-orang di sekitar yang berupaya membantunya memikul beban kehidupan yang ia rasakan. Ketika ia merasa menghadapi 
jalan buntu terhadap kasusnya, ibu berpasrah kepada Tuhan melalui doa dan ia merasa selalu ada jalan yang terbuka baginya.

Sedikit berbeda dari ibu, wawancara dengan ayah memunculkan beberapa tema sebagai berikut.

\section{Tema pada Ayah 1: Kesedihan yang Mendalam}

Ketika pertama mengetahui anaknya meninggal, ayah merasa hancur. Ia merasa sedih karena ia belum dapat bertemu dengan anaknya lagi di hari-hari sebelum kematian sang anak. Ayah menyampaikan bahwa ia merasakan perasaan sedih yang mendalam selama 3-4 bulan pertama setelah kejadian kematian anaknya. Ayah menggambarkan kehidupan pernikahan dan kehidupan berkeluarganya sebagai sesuatu yang membahagiakan, namun ia merasa kebahagiaan tersebut terpenggal ketika peristiwa kematian anaknya terjadi. Ayah merasa kaget dan tidak menyangka karena pada mulanya, ia mengira bahwa anaknya hanya tertembak di bagian tubuh lain yang tidak vital. Saat pertama melihat jenazah anaknya, ayah tidak bisa berpikir apa-apa.

"Saya tuh kasian dengan anak saya itu karena dia baru aja sakit, belum sembuh betul, terus ada berapa hari saya gak ketemu karena dia kan nginep di kampus, terus meninggal.. terus saya tuh kayak gak ada.. gak ada pesan apa-apa. Rasanya tuh.. gimana ya.. ya.. ya hancur ya."

Kesedihan mendalam yang dirasakan ayah membuatnya enggan terlibat dalam berbagai aktivitas yang bernuansa gembira, bahkan hingga saat ini. Ayah mengatakan bahwa dirinya seperti hanya ingin menampung kesedihan saja, padahal saat anaknya masih ada, ayah cenderung suka mengikuti aktivitas-aktivitas yang ada di lingkungannya.

\section{Tema pada Ayah 2: Marah dan Dendam}

Ayah mengatakan bahwa ia merasakan perasaan jengkel, marah, dan dendam. Perasaan jengkel didasari oleh pemikiran mengapa terjadi penembakan lagi terhadap mahasiswa, padahal beberapa bulan sebelumnya sudah pernah ada korban yang jatuh. Ayah mengatakan bahwa rasanya ia ingin memukul orang. Ia merasa bahwa dirinya menjadi pemarah dan setiap kali melihat orang lain, ia merasa bahwa orang lain hanya akan mengganggu dirinya. Rasa jengkel dan marah tersebut terkadang juga diluapkan di kantor, bahkan ia pernah melempar kursi karena begitu kesal dengan bagian personalia yang menanyakan terkait absensinya ketika peristiwa kematian anaknya terjadi. Perasaan marah dan jengkel juga membuat dirinya tidak dapat menerima nasihat-nasihat dan 
penghiburan dari orang lain. Namun, sebenarnya ia tidak tahu kepada siapa ia harus menujukkan rasa marah tersebut.

\begin{abstract}
"Mau.. mau apa tuh.. jengkel kepada orang yang menembak anak saya, saya gak tau orangnya yang mana. Terus saya harus apa.. jengkel terhadap orang yang seharusnya bertanggungjawab terhadap itu, terhadap kasus itu. Dan nampaknya kok gak ada ujung pangkalnya ya waktu itu dalam pikiran saya."
\end{abstract}

Ayah menyampaikan pula bahwa sebagai manusia ia merasa dendam terhadap orang yang menembak anaknya, namun ia merasa tidak berdaya menghadapi kekuatan yang lebih besar darinya. Perasaan jengkel kepada penegak hukum juga ia rasakan, di mana ia berpendapat bahwa seharusnya para penegak hukum menjadi wakil rakyat untuk menyelesaikan kasus. Namun, yang ia dapatkan hanyalah berbagai alasan dari para penegak hukum untuk tidak melakukan sesuatu terkait dengan kasus kematian anaknya.

\title{
Tema pada Ayah 3: Tidak Menerima Kematian Anak
}

Peristiwa kematian anak yang tidak terduga, terutama dalam peristiwa kekerasan politik membuat ayah memiliki perasaan tidak terima. Menurutnya, kematian sang anak bukan merupakan hal yang wajar. Kematian yang wajar adalah kematian karena sakit atau kecelakaan, namun dalam kasus anaknya, kematian tersebut disebabkan karena adanya orang yang dengan sengaja membunuh sang anak, sehingga ayah tidak dapat mengampuni maupun mengikhlaskan kematian anaknya hingga saat ini. Menurutnya, hingga sekarang kematian anaknya masih menjadi ganjalan batin.

"Ya, karena meninggalnya anak saya itu boleh dikatakan meninggal gak wajar ya. Gak wajar dalam arti, kalo wajar itu kan karena sakit atau kecelakaan. Ini kan disengaja oleh.. oleh.. oleh orang yang sadar betul bahwa sebenarnya perbuatannya itu kan perbuatan jahat. Itulah sampai sekarang saya gak bisa mengatakan ikhlas betul tuh gak bisa."

Ayah mengakui bahwa ia banyak mendapatkan nasihat dari orang-orang di sekitarnya untuk melupakan dan merelakan kasus kematian anaknya, namun ia tidak dapat menerima kematian sang anak.

\section{Tema pada Ayah 4: Kehilangan Semangat dan Harapan}

Harapan dan masa depan terkait anak hilang bersamaan dengan kepergian anak. Pupusnya harapan itu dapat terlihat dari pernyataan-pernyataan, seperti keinginan untuk melihat anak sukses 
dalam bekerja. Ayah menaruh harapan yang tinggi pada anak pertamanya, bahwa anak tersebut dapat mengangkat harkat keluarga mereka. Pada waktu itu, ayah juga merasa bahwa hari tuanya menjadi tidak bahagia. Reaksi lain yang terlihat pada masa awal ayah ketika menghadapi kematian anak yaitu perasaan hilangnya tujuan hidup. Ayah merasa bahwa tujuan ia bekerja adalah untuk menghidupi keluarganya, sehingga ketika anaknya meninggal, ia merasa tidak tahu lagi untuk apa tujuannya bekerja. Rasa kehilangan tujuan ini juga berdampak pada produktivitas dalam menjalankan peran di kehidupan sehari-hari.

"Emm.. semangat kerja itu.. apanya.. terus gak ada ya.. Dan dengan anak saya gak ada, saya tuh.. untuk apa sih saya tuh harus kerja nyari uang, nyari ini.. karena anak yang saya biayai kok ternyata sudah gak ada. Ya rasa.. sedikit frustrasi, juga ada ... seperti, untuk apa sih semua ini?"

Namun, ayah juga mengatakan bahwa ia tidak bisa berlama-lama larut dalam perasaan kehilangan semangat karena masih ada anak kedua yang juga menjadi tanggung jawabnya. Setelah 4 bulan sejak kematian anak pertamanya, ayah merasa bahwa ia harus bangkit kembali. Meskipun demikian, kejadian kematian sang anak tetap menjadi bahan pikirannya bahkan di saat bekerja.

\section{Tema pada Ayah 5: Menutupi Kesedihan}

Meskipun merasakan perasaan sedih yang mendalam, ayah merasa ia harus bisa menahan diri untuk tidak menunjukkan kesedihan itu, terutama karena ia mengerti bahwa istri dan anak keduanya juga merasakan kesedihan. Ketika istrinya berada di masa tidak ingin mengurus rumah, ayah mengambil alih tanggung jawab sang istri dengan menggantikannya memasak dan membersihkan rumah. Terkadang ketika merasa sangat sedih, ayah hanya diam saja di kantor, namun karena teman-temannya mengerti, mereka tidak mengatakan apa-apa pada dirinya.

"Jadi saya juga ini ya.. saya sadar waktu itu ya.. saya harus bisa mengendalikan diri saya sendiri. Tapi saya juga harus bisa ee.. menerima perasaan dia, perasaan anak saya yang kedua ... Saya juga sedih tapi gak bisa berbuat apa-apa. Karena.. ee.. saya bisa.. saya bisa apa ya.. ngemong perasaan dia ya. Dalam kesedihan bener itu saya berusaha untuk tidak saya tampilkan gitu."

\section{Tema pada Ayah 6: Bangkit karena Dukungan Sosial}

Ayah juga merasa bahwa dukungan sosial dari orang-orang sangat membantu. Teman-teman di kantornya juga dirasa sangat memahami dirinya sehingga memaklumi jika terkadang ia mudah marah atau tidak fokus di kantor. Menurutnya, tetangga dan teman-temannya tidak ada yang 
mencibir keluarga mereka. Ayah tergerak oleh perhatian dan empati dari orang lain, terkait dengan pengorbanan anaknya, sehingga ia mulai menuliskan ucapan terima kasih kepada mereka satu per satu. Ternyata kegiatan menulis ucapan terima kasih tersebut membantu ayah untuk bangkit kembali dan mengambil tindakan selanjutnya terkait kasus anaknya.

"Ya apa ya.. rasa itu loh.. terenyuh. Tersentuh, dengan.. ini.. rasa simpati empati dari orangorang terhadap keluarga ini, tapi fokusnya tuh kepada pengorbanan anak saya. Memberikan empati yang sangat dalam sekali, dan itu tuh gak bisa saya.. gak bisa saya lupakan, gak bisa saya tinggalkan sikap-sikap seperti ini. Itu sadar sekali bagi saya.”

Dukungan sosial tidak hanya terbatas pada orang-orang di sekitar yang mengenal ayah dan keluarganya. Pada waktu itu, media massa sangat gencar menyampaikan berita-berita mengenai pergolakan politik, termasuk menyoroti peristiwa kekerasan politik yang terjadi. Pemberitaan oleh media massa yang dianggap cukup objektif membuat ayah merasa dikuatkan untuk memperjuangkan keadilan.

\section{Tema pada Ayah 7: Memperjuangkan Keadilan Hukum}

Pada ayah, perasaan-perasaan seperti rasa jengkel, dendam, dan marah justru menjadi motivasinya untuk bertahan dan memperjuangkan kasus anaknya. Ketika ada lembaga psikologi yang menawarkan bantuan, ayah menolaknya. Ia tidak mau perasaan negatif tersebut hilang, karena ia takut akan kehilangan semangat untuk menuntut menyelesaikan kasus.

"Justru malah.. rasa jengkel, rasa dendam, rasa marah itu, kok pengen saya pelihara, waktu itu. Karena saya ingin menghadapi kasus yang seperti itu."

Menurutnya, emosi-emosi yang ia rasakan tersebutlah yang menjadikan semangatnya tetap menyala untuk menyelesaikan kasus. Hingga saat ini, kesedihan dan kemarahan masih ayah rasakan, namun hal yang menjadi fokus utama bagi dirinya adalah mengenai penyelesaian kasus penembakan anaknya. Ayah terus mengupayakan agar impunitas hukum tidak sampai terjadi.

\section{Tema pada Ayah 8: Keimanan Saja Tidak Cukup}

Ayah mengatakan bahwa kematian anaknya mungkin memang sudah menjadi kehendak Tuhan, namun hal tersebut tidak berarti ia hanya diam dan menerima kematian anaknya. Ia tetap menuntut adanya penyelesaian kasus sesuai dengan hukum yang berlaku. Iman dan hukum 
masyarakat adalah pandangan dirinya yang menurutnya tidak dapat dipisahkan, dan hal tersebut seperti membuat kepribadiannya terbelah.

“Gimana ya... kematian anak saya itu ya... memang kalau... ini ya... saya punya dua pandangan sisi ya, dari sisi iman, memang... memang sudah jadi kehendak yang di Atas ya dia harus menghadap ke sang Khalik. Tapi kalau dari sisi kehidupan bermasyarakat dan hukum ya harus diselesaikan, harus ada penyelesaian secara hukum. Tidak hanya dengan.. karena itu jadi kehendak Tuhan yang mahakuasa, lalu kita ya sudah, gitu loh."

Ayah juga merasa bahwa ia tidak setuju dengan pandangan orang yang mengatakan bahwa kematian anaknya disebabkan karena kesalahan anaknya sendiri. Menurutnya, pada masa itu memang diperlukan seseorang yang bisa menghentikan aksi otoriter dari pemerintah. Jika tidak ada orang yang mengambil tindakan, maka situasi pemerintahan masa itu juga tidak akan berhenti, sehingga ia tidak menyalahkan anaknya yang mengambil posisi terhadap pemerintah, namun ia menyesali cara pemerintah dalam menghadapi kritikan masyarakat dengan menggunakan senjata tajam.

\section{DISKUSI}

Penelitian ini bertujuan untuk mendalami pengalaman orang tua yang kehilangan anaknya dalam peristiwa kekerasan politik. Hasil wawancara dengan kedua partisipan memunculkan beberapa tema dalam proses pemaknaan mereka. Terdapat perbedaan dan persamaan di dalam tema-tema yang muncul antara ayah dan ibu sebagai orang tua. Hasil penelitian ini menunjukkan bahwa meskipun beberapa tahun telah berlalu semenjak kematian anak mereka, ayah dan ibu masih mengalami perasaan kehilangan dan reaksi duka.

Seperti yang sudah ditemukan dalam penelitian sebelumnya, situasi terkait penyebab kematian anak menjadi prediktor yang kuat terhadap proses penyesuaian diri orang tua, di mana kematian yang tidak terduga berasosiasi dengan reaksi duka yang lebih intens (Lichtenthal, Neimeyer, Currier, Roberts, \& Jordan, 2013; Stroebe dkk.,2013; Wijngaards-de Meij et al, 2005). Individu yang tidak siap menerima kematian anak memiliki resiko yang lebih tinggi untuk mengalami reaksi duka yang kronis atau yang biasa disebut dengan complicated grief. Complicated grief berbeda dari reaksi duka pada wajarnya, ditandai dengan reaksi duka yang lebih intens dan berdampak pada keberfungsian sehari-hari.

Complicated grief sendiri dapat dideskripsikan sebagai keinginan kuat untuk bertemu dengan individu yang sudah meninggal, kesulitan dalam menerima peristiwa kematian, dan kesulitan untuk 
melanjutkan hidup (Prigerson et al., 2009). Gejala tersebut dapat bertahan selama waktu tertentu, mulai dari enam bulan sampai bertahun-tahun. Complicated grief umumnya muncul pada individu yang mengalami kehilangan karena peristiwa kekerasan, di mana kematian tersebut juga tidak terduga (Prigerson et al., 2009). Gejala complicated grief ditemukan pula dalam hasil penelitian ini, di mana ibu mengalami kesulitan untuk beradaptasi dalam menghadapi kematian anaknya hingga bertahun-tahun, sedangkan ayah mendeskripsikan adanya perasaan marah, jengkel, dan dendam yang masih bertahan hingga saat ini. Ibu mendeskripsikan duka mereka sebagai perasaan mati rasa yang berkelanjutan, hingga sekarang, di mana hal ini ditemukan pula dalam analisis yang dilakukan oleh Bauwens (2017) dalam grey literature.

Reaksi duka yang muncul dari ibu adalah perasaan mati rasa. Perasaan mati rasa ini dapat dijelaskan dengan istilah emotional numbness yang menggambarkan suatu fenomena dimana individu tidak dapat merasakan apa-apa. Emotional numbness merupakan salah satu gejala dalam complicated grief (American Psychological Association, 2013; Prigerson et al., 2009). Berbeda dengan tahapan duka yang diperkenalkan oleh Kubler-Ross (1970), di mana tahapan diawali dengan denial, anger, bargaining, depression, dan acceptance, ibu pada penelitian ini tidak mengalami tahapan denial dan bargaining. Hal ini mungkin karena ibu juga memahami situasi politik dan risiko yang mungkin terjadi di masa itu. Hanya saja, kematian anaknya yang tiba-tiba membuat ibu mengalami tahapan marah dan depresi. Ibu sempat menangis dan menarik diri selama beberapa waktu.

Rasa marah juga dialami ayah dan rasa marah tersebut diluapkan di tempat kerja. Ayah melihat anaknya sebagai penerus keluarga, sedangkan kematian anak lelaki pertamanya membuat ia kehilangan harapan tersebut. Menurut tahap perkembangan Erikson, usia paruh baya merupakan masa dimana individu mengembangkan peran generativity, yaitu kebutuhan untuk mengasuh dan membimbing generasi yang lebih muda (Papalia, Martorell, \& Feldman, 2012). Oleh karena itu, kehilangan anak pada usia ini dapat berpengaruh pula pada tahap perkembangan dan identitas peran orang tua.

Meskipun sempat merasa kehilangan semangat dan harapan, ayah merasa bahwa ia harus bangkit kembali dan melanjutkan hidup untuk menghidupi anak keduanya. Hal ini sejalan pula dengan penelitian oleh Dyregrov, Dyregrov, dan Kristensen (2016) yang mengatakan bahwa anak lain di dalam keluarga dapat menjadi alasan orang tua untuk mampu bangkit kembali. Dalam penelitian ini, ayah mengatakan bahwa sampai saat ini ia tidak bisa menerima kematian anaknya dengan ikhlas karena kematian anaknya bukan disebabkan oleh suatu hal yang wajar. Hasil ini 
didukung oleh penelitian Lichtenthal, Neimeyer, Currier, Roberts, dan Jordan (2013) yang menjelaskan bahwa orang tua akan lebih mudah untuk memproses kematian anak jika kematian tersebut disebabkan oleh hal yang natural. Penelitian lain juga mengemukakan bahwa orang tua yang berduka dapat menjadi terbiasa seiring berjalannya waktu, namun tidak akan pernah bisa melupakannya (Arnold \& Gemma, 2008).

Perasaan tidak berdaya karena menjadi bagian dari sistem yang lebih luas terlihat dari cara ibu memandang dirinya sendiri sebagai korban, sedangkan pada ayah, hal tersebut diungkapkan dalam ketidakmampuannya untuk melakukan sesuatu terhadap kekuatan yang lebih besar darinya. Kejadian kematian anaknya dalam peristiwa kekerasan politik juga mengubah cara pandangnya akan dunia, di mana dunia dipersepsikan sebagai tempat yang kejam dan keluarganya adalah korban di dalam sistem tersebut. Analisis ini didukung oleh penelitian Currier, Holland dan Neimeyer (2009) yang menyatakan bahwa peristiwa kematian seorang yang disayangi dapat mengubah pandangan individu akan dirinya dan dunianya. Pada individu yang berduka, mereka cenderung melihat dirinya lebih tidak berharga dan menilai dunia sebagai tempat yang penuh kejahatan.

Penelitian Stroebe, Schut, dan Finkenauer (2013) juga menemukan bahwa kematian anak mengubah kehidupan orang tua, baik secara individu maupun relasi dalam keluarga. Keluarga mereka yang awalnya hangat menjadi memiliki masalah komunikasi di mana lebih banyak waktu dihabiskan sendiri-sendiri dalam diam. Terdapat perbedaan cara adaptasi antara ibu dan ayah, di mana ibu terlihat lebih ter-preokupasi dengan kematian anak dibandingkan dengan ayah. Ayah berusaha untuk tidak menunjukkan emosinya, di mana ia lebih banyak melakukan aktivitas lain seperti membaca koran atau menulis, baik di rumah maupun di kantor. Hasil ini sesuai dengan penelitian oleh Stroebe dkk. (2013) yang menemukan bahwa suami cenderung menahan reaksi duka mereka dan berusaha terlihat kuat, dengan maksud untuk melindungi perasaan pasangan mereka. Perbedaan gender dalam meresponi stres dan peran gender mengenai norma dalam mengekspresikan emosi juga dapat menjelaskan usaha ayah untuk tidak menunjukkan kesedihannya tersebut (Dyregrov, Dyregrov, \& Kristensen, 2015).

Sesuai dengan hasil penelitian Stroebe, Schut, dan Finkenauer (2013), tidak ada cara spesifik dalam berduka, namun setiap individu memiliki cara berduka masing-masing. Hal ini terlihat dari persamaan maupun perbedaan yang ada dalam cara orang tua menanggapi kematian anaknya. Ibu dalam penelitian ini membutuhkan waktu yang lebih lama sebelum akhirnya dapat berfungsi kembali dalam kehidupannya sehari-hari, sedangkan ayah pada penelitian ini dapat bangkit kembali dalam waktu empat bulan setelah kejadian kematian sang anak, meskipun kejadian tersebut banyak 
memengaruhi produktivitasnya. Dalam studi Dyregrov, Dyregrov, dan Kristensen (2015) ditemukan bahwa ibu mengalami reaksi duka yang lebih intens seiring berjalannya waktu dibandingkan dengan ayah.

Pada mulanya, ibu cenderung menarik diri dari orang-orang sekitar, namun kemudian dukungan sosial yang begitu kuat dari orang-orang di sekitar menguatkan ibu dan ayah untuk bangkit kembali. Temuan ini didukung oleh penelitian-penelitian sebelumnya (Dyregrov, Dyregrov, \& Kristensen, 2016; Stroebe dkk., 2013), di mana dukungan sosial menjadi salah satu faktor yang membantu orang tua untuk menghadapi kematian anaknya. Ibu dan ayah sama-sama mengatakan bahwa mungkin kematian anak mereka sudah dikehendaki oleh Tuhan. Kematian karena kekerasan adalah suatu hal yang mendadak dan tidak terduga, sehingga orang tua tidak memiliki waktu untuk mencerna kematian tersebut. Oleh karena itu, pemaknaan peristiwa kematian anak seringkali dikaitkan dengan keyakinan bahwa kematian anak mereka merupakan bagian dari rencana Tuhan (Lichtenthal , Neimeyer, Currier, Roberts, \& Jordan, 2013). Namun ayah menyampaikan bahwa dengan melihat kematian anaknya sebagai bagian dari kehendak Tuhan, bukan berarti ia tidak melakukan apa-apa. Ayah tetap menuntut adanya keadilan hukum bagi kasus tersebut.

Dalam studi oleh Lichtenthal, Currier, Neimeyer, \& Keesee (2010), ditemukan bahwa tema yang paling sering muncul terkait dengan pemaknaan dari peristiwa kematian anak adalah keinginan untuk membantu dan menunjukkan kasih kepada orang lain yang mengalami penderitaan yang sama. Hal yang sama juga terlihat dalam motivasi yang menguatkan ibu dalam penelitian ini untuk terus memperjuangkan keadilan, tidak hanya untuk kasus anaknya sendiri, namun juga untuk kasus-kasus lain. Perjuangan tersebut direalisasikan dengan membentuk paguyuban keluarga korban dan melaksanakan aksi rutin. Membentuk komunitas bersama dengan keluarga lain yang juga berduka dapat menjadi salah satu cara untuk menjembatani perasaan tidak berdaya (Bauwens, 2017). Selain itu, proses adaptasi yang bersifat aktif dapat membantu memfasilitasi pemaknaan terhadap kematian anak (Dyregrov, Dyregrov, \& Kristensen, 2015).

Penelitian ini mengangkat kasus kematian anak yang disebabkan oleh kekerasan politik. Penelitian ini unik dan berbeda karena kekerasan politik adalah peristiwa yang sebenarnya tidak umum terjadi, sehingga reaksi-reaksi emosional yang muncul pada partisipan penelitian mungkin tidak sama dengan kasus kehilangan yang lebih umum, seperti kematian karena kecelakaan atau penyakit. Partisipan dalam penelitian ini memiliki kepercayaan bahwa kematian anak mereka adalah hal yang disengaja oleh pihak aparat. Mereka memandang peristiwa kematian anak mereka disebabkan oleh pembunuhan melalui tembakan yang sengaja diarahkan ke jantung sang anak. 
Reaksi duka terkait kematian anak karena peristiwa kekerasan memunculkan emosi negatif seperti perasaan marah, benci, dan dendam terhadap sosok yang menghilangkan nyawa anak (Saka \& Cohen-Louck, 2014). Reaksi yang sama muncul pada diri ayah dalam penelitian ini, bahkan emosi negatif tersebut tetap bertahan hingga saat ini.

Meskipun 20 tahun sudah berlalu sejak peristiwa kematian anaknya, ayah tidak mau kehilangan emosi negatif, seperti: perasaan marah dan dendam yang ia rasakan. Bahkan, ayah tidak mau bertemu dengan psikolog karena tidak ingin kehilangan rasa marahnya tersebut karena emosi negatif tersebutlah yang menjadi motivasinya untuk menuntut penyelesaian kasus anaknya. Penelitian sebelumnya oleh Peach \& Klass (1987) berupaya menjelaskan berbagai faktor yang dialami orang tua terkait dengan kematian anaknya akibat pembunuhan. Salah satunya, proses hukum yang berbelit dan dianggap tidak adil membuat duka orang tua tidak dapat terselesaikan. Kemungkinan penjelasan ini juga sesuai dengan hasil penelitian, di mana ayah tidak mau atau belum bisa menghilangkan emosi negatif, seperti marah, jengkel, dan dendam yang ia rasakan selama belum ada penyelesaian hukum terkait kasus kematian anaknya.

Proses duka partisipan adalah perjalanan seumur hidup, di mana partisipan mengalami perubahan seumur hidup yang mengubah identitas dan perspektif mereka akan hidup (Arnold \& Gemma, 2008). Dalam penelitian ini, partisipan mengalami banyak perubahan baik secara individu maupun dalam identitas perannya. Ibu yang awalnya hanya seorang pegawai negeri dan ibu rumah tangga, kini juga menjadi aktivis pejuang hak asasi manusia, penulis, dan pembicara di berbagai acara. Begitu pula dengan ayah yang ikut memperjuangkan kasus bersama dengan istrinya, dengan mengatur dan merencanakan langkah-langkah yang akan mereka tempuh untuk menegakkan hukum. Kematian anak juga mengubah pandangan orang tua terhadap hidup, di mana mereka melihat perjuangan anaknya sebagai sesuatu yang memang diperlukan pada saat itu, guna menyikapi pemerintahan yang tidak sesuai dengan harapan masyarakat. Complicated grief dan emosi-emosi negatif yang dirasakan partisipan mendorong mereka untuk melakukan tindakan nyata terkait kematian sang anak. Mereka kemudian memaknai kematian anak dengan melanjutkan perjuangan sang anak melalui aksi nyata dalam menegakkan hak asasi manusia, dengan maksud agar kematian anak mereka tidak menjadi sia-sia. 


\section{SIMPULAN DAN SARAN}

\section{Simpulan}

Kematian anak menjadi hal yang sulit untuk dicerna dan diterima oleh partisipan, terlebih lagi karena kematian tersebut disebabkan oleh kekerasan, di mana dalam penelitian ini kekerasan yang dimaksud adalah kekerasan politik. Hasil penelitian menunjukkan bahwa baik ayah maupun ibu masih mengalami reaksi duka hingga saat ini, meskipun sudah 20 tahun berlalu sejak kematian anak mereka. Tema-tema seperti kesedihan, kemarahan, perasaan tidak terima, dan emosi-emosi negatif lainnya muncul dan cukup mendominasi. Peneliti menarik kesimpulan bahwa mungkin ada proses complicated grief, yaitu keinginan kuat untuk bertemu dengan individu yang sudah meninggal, kesulitan dalam menerima peristiwa kematian, dan kesulitan untuk melanjutkan hidup (Prigerson et al., 2009), karena peristiwa kematian anak yang tidak terduga membuat partisipan lebih sulit untuk menyesuaikan diri (Song, Floyd, Seltzer, Greenberg, \& Hong, 2010).

Salah satu hal yang membantu partisipan bangkit adalah besarnya dukungan sosial yang mereka terima. Lebih lanjut, complicated grief yang dirasakan partisipan mendorong mereka untuk melakukan suatu tindakan. Partisipan kemudian melakukan aksi-aksi untuk meneruskan perjuangan anaknya, sambil tetap menuntut penyelesaian hukum atas kasus kematian anak mereka. Pada ibu, aksi untuk memperjuangkan kematian anaknya berkembang pula menjadi keinginan untuk membantu orang lain yang mengalami hal serupa. Sementara itu, pada ayah, emosi negatif, seperti perasaan marah dan dendam menjadi hal yang menguatkan dirinya untuk terus berjuang menegakkan keadilan demi memaknai kematian sang anak. Dapat dilihat bahwa partisipan memaknai kematian anak mereka dengan melanjutkan perjuangan reformasi agar kematian sang anak tidak menjadi sia-sia.

\section{Saran Teoretis}

Diperlukan pengembangan penelitian lebih lanjut terkait dengan hasil yang diperoleh. Pengembangan penelitian dapat dilakukan dengan menggabungkan metode penelitian kualitatif dan kuantitatif dalam pengambilan data, sehingga hasil penelitian menjadi lebih kaya. Dapat diukur pula variabel spesifik terkait dengan grieving ataupun kondisi kesehatan mental partisipan secara umum, untuk mengetahui secara lebih mendalam kondisi psikologis partisipan. Sampel penelitian juga dapat ditambah guna mendapatkan gambaran yang lebih menyeluruh terkait dengan pemaknaan orang tua terhadap kematian anak dalam konteks kekerasan politik. 


\section{Saran Praktis}

Salah satu implikasi penelitian ini bagi praktisi klinis adalah untuk memiliki pengetahuan mendalam akan perasaan duka orang tua dan berusaha memahami cara pandang orang tua guna dapat membantu mereka secara efektif. Psikolog dapat menyediakan terapi client-centered yang sesuai untuk memberikan validasi terhadap berbagai emosi orang tua yang kehilangan anaknya dalam peristiwa kekerasan politik serta membantu mereka untuk memaknai peristiwa kematian anak.

Hasil penelitian juga menunjukkan bahwa dukungan sosial menjadi sesuatu yang penting bagi orang tua yang kehilangan anaknya dalam peristiwa kekerasan politik untuk dapat menemukan makna dari kejadian tersebut. Oleh karena itu, ketersediaan support group atau komunitas keluarga yang berduka disertai dengan fasilitator psikologis dapat membantu orang tua untuk memiliki perasaan terhubung satu sama lain dan saling menguatkan. Terkait dengan temuan penelitian bahwa ada kemungkinan orang tua korban tidak ingin bertemu psikolog untuk melakukan konseling karena perasaan marah yang begitu besar, psikolog dapat menyediakan terapi kelompok. Bentuk terapi kelompok yang mirip dengan support group memungkinkan orang tua korban untuk saling berbagi cerita dengan korban lain, sekaligus mendapatkan manfaat terapeutik dari interaksi kelompok itu sendiri.

Masyarakat dan lingkungan sekitar juga dapat turut membantu orang tua dengan bersikap tidak menghakimi dan menunjukkan penerimaan, serta memberikan dukungan yang terus-menerus seiring berjalannya waktu, mengingat bahwa proses duka adalah perjalanan seumur hidup.

\section{UCAPAN TERIMA KASIH}

Ucapan terima kasih yang besar kami sampaikan kepada kedua orang tua yang menjadi partisipan dalam penelitian ini dan bersedia membagikan pengalaman hidupnya.

\section{REFERENSI}

American Psychological Association (APA). (2013). Diagnostic and Statistical Manual of Mental Disorders (5th ed). American Psychiatric Association, Washington, D.C.

Arnold, J. \& Gemma, P. (2008). The continuing process of parental grief. Death Studies, 32, 658673. 
Bauwens, J. (2017). Losing a family member in an act of terror: A review from the qualitative grey literature on the long-term affects of September 11, 2001. Clinical and Social Work Journal, 45, 146-158. doi: 10.1007/s10615-017-0621

Creswell, J. W. (2007). Qualitative inquiry and research design: Choosing among five approaches (2nd ed.). Thousand Oaks, CA: Sage Publications, Inc.

Dyregrov, K., Dyregrov, A., \& Kristensen, P. (2015). Traumatic bereavement and terror: The psychosocial impact on parents and siblings 1.5 years after the July 2011 terror killings in Norway. Journal of Loss and Trauma, 20(6), 556-576. doi: $10.1080 / 15325024.2014 .957603$

Dyregrov, K., Dyregrov, A., \& Kristensen, P. (2016). In what ways do bereaved parents after terror go on with their lives, and what seems to inhibit or promote adaptation during their grieving process? A qualitative study. Journal of Death and Dying, 73(4), 374-399. doi: $10.1177 / 0030222816653851$

Kristensen, P., Weisæth, L., \& Heir, T. (2012). Bereavement and mental health after sudden and violent losses: A review. Psychiatry: Interpersonal and Biological Processes, 75(1), 7697.

Kübler-Ross, E. (1970). On death and dying. London: Taylor and Francis.

Kumar, R. (2011). Research methodology, a step-by-step guide for beginners (3rd ed.). London, UK: Sage Publication.

Lestari, S. (2018). Kasus penembakan mahasiswa Trisakti, Semanggi I dan II, belum selesai setelah 20 Tahun Reformasi. BBC Indonesia. Ditemu kembali dari https://www.bbc.com/indonesia/indonesia-43940189

Lichtenthal, W., Currier, J., Neimeyer, R., \& Keesee, N. (2010). Sense and significance: A mixed methods examination of meaning making after the loss of one's child. Journal of Clinical Psychology, 66(7), 791-812. doi: 10.1002/jclp.20700

Lichtenthal, W. G., Neimeyer, R. A., Currier, J. M., Roberts, K., \& Jordan, N. (2013). Cause of death and the quest for meaning after the loss of a child. Death Studies, 37(4), 311-342. doi: 10.1080/07481187.2012.673533

Matthews, L. T., \& Marwit, S. J. (2004). Examining the assumptive world views of parents bereaved by accident, murder, and illness. Omega, 48(2), 115-136. doi: 10.2190/KCB0NNVB-UGY6-NPYR 
Murphy, S. A., Johnson, L. C., Chung, I. J., \& Beaton, R. D. (2003). The incidence of PTSD following the violent death of a child and predictors of change over time. Journal of Traumatic Stress, 16, 17-26.

Murphy, S. A., Johnson, L. C., Wu, L., Fan, J. J., \& Lohan, J. (2003). Bereaved parents' outcomes 4 to 60 months after their children's deaths by accident, suicide, or homicide: A comparative study demonstrating differences. Death Studies, 27(1), 39-61.

Papalia, D. E., Martorell, G., \& Feldman, R. D. (2012). Experience human development (12th ed.). New York, NY: McGraw-Hill.

Peach, M. R. \& Klass, D. (1987). Special issues in the grief of parents of murdered children. Death Studies, 11(2), 81-88. doi: 10.1080/07481188708252179

Prigerson, H. G., Horowitz, M. J., Jacobs, S.C., Parkes, C. M., Aslan, M., Goodkin, K., Maciejewski, P. K. (2009). Prolonged grief disorder: Psychometric validation of criteria proposed for DSM-V and ICD-11. PLoS Medicine, 6(8). doi: 10.1371/journal.pmed.1000121

Saka, Y., \& Cohen-Louck, K. (2014). From demonization to identification: How parents who lost children in terrorist attacks perceive the attacker. Journal of Loss and Trauma: International Perspectives on Stress \& Coping, 19(2), 137-154. doi: $10.1080 / 15325024.2012 .743323$

Song, J., Floyd, F. J., Seltzer, M. M., Greenberg, J. S., \& Hong, J. (2010). Long-term effects of child death on parents' health-related quality of life: A dyadic analysis. Fam. Relat., 59(3), 269-282. doi: 10.1111/j.1741-3729.2010.00601.x

Stroebe, M., Schut, H., \& Finkenauer, C. (2013). Parents coping with the death of their child: From individual to interpersonal to interactive perspectives. Family Science, 4(1), 28-36. doi: $10.1080 / 19424620.2013 .819229$

Wijngaards-de Meij, L., Stroebe, M., Schut, H., Stroebe, W., van den Bout, J., van derHeijden, P., $\&$ Dijkstra, I. (2005). Couples at risk following the death of their child: Predictors of grief versus depression. Journal of Consulting and Clinical Psychology, 73, 617-623. doi: 10.1037/0022006X.73.4.617

Wijngaards-de Meij, L., Stroebe, M., Stroebe, W., Schut, H., van den Bout, J., van derHeijden, P., \& Dijkstra, I. (2008). The impact of circumstances surrounding the death of a child on parents' grief. Death Studies, 32(3), 237-252. doi: 10.1080/07481180701881263 
Worden, J. W. (2008). Grief counseling and grief therapy a handbook for the mental health practitioner (4th ed.). New York, NY: Springer Publishing Company. 